\title{
Biochemical parameters of an Oxisol submitted to high doses of gypsum in the coffee culture
}

\author{
Andrêssa de Paula Naves ${ }^{1}$ (D), Aline Oliveira Silva1 (iD, Marisângela Viana Barbosa1 (iD), Flávio Araújo Pinto1 (iD), Jessé Valentim \\ dos Santos $^{1}$ (D), Orivaldo José Saggin Junior ${ }^{2}$ (D), Paulo Tácito Gontijo Guimarães ${ }^{3}$ (D), Marco Aurélio Carbone Carneiro ${ }^{1}$ (D)
}

${ }^{1}$ Universidade Federal de Lavras (UFLA), Lavras, MG, Brasil

${ }^{2}$ Empresa Brasileira de Pesquisa Agropecúaria/Embrapa, Centro Nacional de Pesquisa de Agrobiologia, Seropédica, RJ, Brasil

${ }^{3}$ Empresa de Pesquisa Agropecuária de Minas Gerais/EPAMIG, Centro Tecnológico do Sul de Minas, Lavras, MG, Brasil

Contact authors: adressap.naves@hotmail.com, alineoliveirasilva6@gmail.com, mvbarbosa10@gmail.com, flavioaraujo10@gmail.com, jessevalentim@gmail.com, orivaldo.saggin@ embrapa.br, paulotgg@epamig.ufla.br, marcocarbone@ufla.br

Received in April 28, 2020 and approved in July 17, 2020

\section{ABSTRACT}

The objective of this study was to determine the influence of increasing doses of agricultural gypsum on the quality of the soil biochemical parameters in coffee cultivation (Coffea arabica L.) over two climatic seasons in the Brazilian Cerrado. Soil samples were collected in two seasons (dry and rainy season),

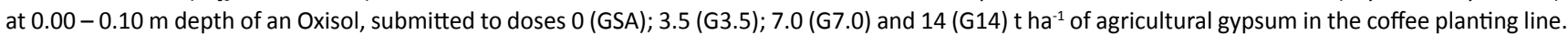
The biochemical parameters evaluated were: total organic carbon (TOC); microbial biomass carbon (MBC); soil basal respiration (SBR); absolute enzymatic activities [Urease, acid phosphatase, hydrolysis of fluorescein diacetate (FDA)], and enzymatic activity per unit of MBC. The significant effect ( $\mathrm{p} \leq 0.05$ ) of gypsum doses was observed for MBC and SBR, which were higher in the treatment with G7.0 application. TOC, the enzymatic activities of Phosphatase and the FDA showed no differences between treatments. On the other hand, the specific enzymatic activities by MBC were used to describe the differences between the doses of gypsum applied, generally with greater activity in treatments G7.0 and G14. The accumulated coffee productivity was higher in G14 treatment. The results presented confirmed that the biochemical parameters of the soil are key in the evaluation of changes in soil use, and that the increase in gypsum favors activity and microbial biomass.

Key words: Coffea arabica; Bioindicators; Soil enzymes

\section{INTRODUCTION}

Coffee is one of the most important agricultural commodities in the world, representing one of the main plants grown in tropical and subtropical countries. Currently, Brazil is the largest coffee producer, accounting for $32.4 \%$ of world production, estimated at about 158.93 million bags for the 2017 - 18 crops, the species cultivated being Coffea arabica and Coffea canephora (Couto et al., 2019; Santos et al., 2019).

Among the Brazilian areas with great potential for the expansion of coffee production are the Cerrado, one of the main biomes in the country and the second largest biome in South America, being acknowledged as a biodiversity hot spot worldwide (Myers et al., 2000). This biome presents well defined climatic seasons with dry winters and rainy summers as well as soils with peculiar characteristics, which are generally deep, naturally acidic, with low natural fertility and high toxicity of aluminum $\left(\mathrm{Al}^{+3}\right)$ in their surface and subsurface (Castro et al., 2016; Lopes; Guilherme, 2016; Mendes et al., 2012).

Therefore, Cerrado soils require applications of special techniques and management that reduce chemical limitations with the use of correctives and conditioners, that aim to improve the edaphic environment for the development and deepening of root systems, therefore allowing the plants to explore more soil, absorbing water and nutrients (Lopes; Guilherme, 2016; Serafim et al., 2013).

The application of agricultural gypsum is done in order to provide calcium and sulfur in depth, and to reduce the toxicity of $\mathrm{Al}^{+3}$ in the subsurface (Sumner, 1995), which can improve the plant's resistance to long periods of drought, as in the Cerrado's dry season (Serafim et al., 2013). The use of gypsum as a soil conditioner in depth is a practice employed disparately regarding its conditions of use and management. Several studies have been carried out on the use of high doses of gypsum in the coffee crop, with effects that range from the increase of the $\mathrm{Ca}^{+2}$ concentration in the soil solution (Ramos et al., 2013), to the highest uniform distribution of the root system (Carducci et al., 2014a; Carducci et al., 2014b; Carducci et al., 2015; Serafim et al., 2013), to the reduction of susceptibility to soil disintegration (Silva et al., 2013, Silva et al., 2014), to the reduction of crop water deficit (Silva et al., 2015), to the soil moisture percentage and coffee yield (Silva et al., 2019a). However, there are no reports on the effect of applying high doses of gypsum on the biological and biochemical parameters of the soil in coffee cultivation.

Biological parameters are considered the most sensitive in the monitoring of changes in soil management (Carneiro et al., 2009; Doran; Zeiss, 2000) since they are responsible for the performance and maintenance of important ecosystem processes. The quantification of soil biochemical parameters, 
such as microbial biomass carbon, basal respiration and enzymatic activities are used as quality bioindicators, since they provide important information for making decisions about which management technique should be adopted (Mendes et al., 2012; Lopes et al., 2013; Silva et al., 2018). Considering the benefits of gypsum for the coffee, mainly in the areas of the Cerrado, the application of high doses of agricultural gypsum in coffee plantations needs to be evaluated for changes in soil biochemical parameters as well as coffee productivity. Therefore, the objective of this study was to evaluate the effect that the application of high doses of agricultural gypsum in the soil in coffee cultivation have on the biomass and the microbial activities of the soil and the productivity of the crop.

\section{MATERIAL AND METHODS}

\subsection{Area of study and experimental design}

The study was installed and conducted in the physiographic region of Upper São Francisco (MG - Brazil), in a coffee plantation cultivated since 2008 at the AP Family Farm in the municipality of São Roque de Minas $\left(20^{\circ} 15^{\prime} 45^{\prime}\right.$ 'S, $\left.46^{\circ} 17^{\prime} 17^{\prime \prime} \mathrm{W}\right)$, with an average altitude of $850 \mathrm{~m}$. The climate of the region is classified as Cwa - subtropical of dry winter and hot and humid summer, according to its Köppen classification, with an average annual rainfall of $1.344 \mathrm{~mm}$ and average annual temperature of $20.7{ }^{\circ} \mathrm{C}$. The soil was classified as an Oxisol (typical dystrophic Red Latosol) with a very clayey texture $\left(660,290,50 \mathrm{~g} \mathrm{~kg}^{-1}\right.$ of clay, silt, and sand, respectively), presenting the chemical characteristics depicted in Table 1.

Table 1: Chemical composition of the soil under coffee cultivation submitted to different doses of agricultural gypsum, in the depth of $0.00-0.10 \mathrm{~m}$. GSA: no agricultural gypsum application; G3.5: $3.5 \mathrm{t} \mathrm{ha}^{-1}$ of agricultural gypsum; G7.0: 7.0 $\mathrm{t} \mathrm{ha}^{-1}$ of agricultural gypsum; G14: $14 \mathrm{t} \mathrm{ha}^{-1}$ of agricultural gypsum.

\begin{tabular}{cccccccc}
\hline Treatments & $\mathrm{pH}$ & $\mathrm{K}^{+}$ & $\mathrm{P}$ & $\mathrm{Ca}^{+2}$ & $\mathrm{Mg}^{+2}$ & $\mathrm{Al}^{+3}$ & $\mathrm{CTC}$ \\
\hline $\mathrm{t} \mathrm{ha}^{-1}$ & $\mathrm{H}_{2} \mathrm{O}$ & $--\mathrm{mg}^{-3} \mathrm{dm}^{-3}--$ & $-----------\mathrm{cmol}_{\mathrm{c}} \mathrm{dm}^{-3}-----------$ \\
\hline $\mathrm{GSA}$ & 5.0 & 170 & 0.6 & 0.6 & 0.2 & 0.1 & 1.34 \\
$\mathrm{G} 3.5$ & 4.3 & 192 & 1.2 & 1.3 & 0.5 & 0.0 & 2.29 \\
$\mathrm{G} 7.0$ & 4.9 & 171 & 2.5 & 1.8 & 0.6 & 0.0 & 2.84 \\
$\mathrm{G} 14$ & 4.0 & 203 & 1.5 & 1.6 & 0.4 & 0.0 & 2.52 \\
\hline
\end{tabular}

The study consisted of a randomized block design, considering the treatments with the doses of agricultural gypsum: 0 (GSA); 3.5 (G3.5); 7.0 (G7.0) and 14 (G14) t ha-1, with three replicates, totaling 12 experimental plots. The plots consisted of 10 planting lines with $21 \mathrm{~m}$ long, each of which consisted of 36 plants with a spacing of $2.5 \times 0.65 \mathrm{~m}$, totaling 360 plants per plot.

The experimental area was implemented in 2008, using a semi-integrated planting system with 6060 plants ha ${ }^{-1}$. The seedlings used were Catucaí Amarelo Multilínea (Coffea arabica). The coffee seedlings were planted at the beginning of the rainy season, October 2008, with the replanting done until December. Regarding the soil preparation, a plowing and two harrows were applied with total area corrections (dolomitic limestone $4 \mathrm{t} \mathrm{ha}^{-1}+1.92 \mathrm{t} \mathrm{ha}^{-1}$ gypsum) and fertilization was applied to the planting line with a formulation (08-44-0) enriched with $1.0 \% \mathrm{Zn}$ and $0.5 \% \mathrm{~B}$ in the amount of $980 \mathrm{~kg} \mathrm{ha}^{-1}$ and $\mathrm{K}$ supplied through the formulation (20-020) $530 \mathrm{~kg} \mathrm{ha}^{-1}$.

The planting of the coffee tree seedlings was in grooves, using a fertilizer for the opening of the planting groove, $0.60 \mathrm{~m}$ deep and $0.50 \mathrm{~m}$ wide. In between the lines of the culture, braquiaria (Urochloa decumbens), that are managed together with the coffee tree were cultivated. After the planting of the seedlings, fertilization with $31 \%$ of $\mathrm{N}$ and $11 \%$ of $\mathrm{P}_{2} \mathrm{O}_{5}$ was performed, and $0.30 \mathrm{~kg}$ per plant was applied in a total of $160 \mathrm{~kg} \mathrm{ha}^{-1}$. During the experiment, the production fertilizations were performed according to the visual diagnosis and chemical analysis of the soil and leaves, but being the same for all treatments. Four months after planting, there was an application of gypsum over the planting lines in their respective treatment doses. In February 2009, during the rainy season, the gypsum was applied to the surface of the cultivation line, without incorporation, in the specific amounts required by each treatment.

\subsection{Soil sampling and analyzed variables}

The soil samples were collected from the coffee planting lines over two seasons: at the end of the rainy season (May - 2014) and at the end of the dry season (September - 2014), where about two $\mathrm{kg}$ of soil were collected at $0.00-$ $0.10 \mathrm{~m}$ depth on the plot's centerline, the projection of the tree canopy and in three sampling points. The centerline of each plot was used for sampling, with the bordering of the first five plants located at the beginning of each line. After collection, the samples were stored in polystyrene boxes and immediately sent to the laboratory, where they were sieved in a $2 \mathrm{~mm}$ mesh and stored in a cold room at $4{ }^{\circ} \mathrm{C}$.

Total organic carbon (TOC) was determined by oxidation with potassium dichromate in the presence of $\mathrm{H}_{2} \mathrm{SO}_{4}$, followed by titration with an ammonia ferrous sulphate solution and a diphenylamine indicator (1\%) (Walkley; Black, 1934). The determination of the microbial biomass carbon (MBC) was done via fumigation with chloroform and extraction with potassium sulphate $\left(0.5 \mathrm{~mol} \mathrm{~L}^{-1}\right)$, followed by oxidation with potassium dichromate $\left(0.066 \mathrm{~mol} \mathrm{~L}^{-1}\right)$ in the presence of acids $\left(\mathrm{H}_{2} \mathrm{SO}_{4}\right.$ and $\left.\mathrm{H}_{3} \mathrm{PO}_{4}\right)$ on a hot plate, followed 
by titration with ammoniacal ferrous sulfate $\left(0.033 \mathrm{~mol} \mathrm{~L}^{-1}\right)$ in the presence of the diphenylamine indicator (1\%) (Vance; Brooks; Jenkinson, 1987). The quantification of soil basal respiration (SBR) was performed by capturing the $\mathrm{CO}_{2}$ in a $\mathrm{NaOH}$ solution $\left(0.5 \mathrm{~mol} \mathrm{~L}^{-1}\right)$, which was titrated with $\mathrm{HCl}(0.5$ mol $\mathrm{L}^{-1}$ ), using phenolphthalein $(1 \%)$ as an indicator (Alef, 1995). The metabolic quotient $\left(q \mathrm{CO}_{2}\right)$ was calculated by the SBR/MBC ratio (Anderson; Domsch, 1993) and the microbial quotient ( $q \mathrm{Mic}$ ) by the MBC/TOC expression (Sparling, 1992).

Urease activity (EC 3.5.1.5) (Tabatabai; Bremner, 1972) was estimated via the incubation of the substrate (urea) for two hours, quantifying the ammonia produced by microdistillation (Keeney; Nelson, 1982). Activity of the enzyme acid phosphatase (EC 3.1.3.2) (Eivazi; Tabatabai, 1977) was measured by the optical density difference (OD) in a spectrophotometer at $410 \mathrm{~nm}$, using a $\rho$-nitrophenylphosphate substrate, incubated for one hour at $37^{\circ} \mathrm{C}$. The total enzymatic activity of the soil was estimated by the hydrolysis of fluorescein diacetate (FDA) (Dick; Breakwell; Turco, 1996), with a reading of O.D. spectrophotometer at $490 \mathrm{~nm}$. Lastly, the specific activities of the enzymes in the soil samples were calculated by the ratio between the enzymatic activities and the $\mathrm{MBC}$, according to the methodology proposed by Waldrop, Balser and Firestone (2000).

The productivity of the coffee trees was measured during the harvests of 2011, 2012, 2013 and 2014, from this data the accumulated productivity of these production years was calculated. The evaluation of the productivity of the coffee plants was carried out using all the plants on the useful lines of each plot and calculated by the productivity value in $\mathrm{kg}$ divided by the size of the sample area, then extrapolating the values for bags ha-1.

\subsection{Statistical analysis}

The variables were submitted to variance analysis $(\mathrm{p} \leq 0.05)$ and the Scott-Knott's test $(\mathrm{p} \leq 0.05)$ comparing the treatments in the two climatic seasons, using Sisvar software (Ferreira, 2011). Principal component analysis (PCA) was performed using $\mathrm{R}$ software ( $\mathrm{R}$ Development Core Team, 2011), to demonstrate the ordering of the treatments and their relation with the biochemical parameters of the soil; eigen values greater than 0.6 were considered to indicate a high association of the major components.

\section{RESULTS}

The total organic carbon (TOC) did not show significant differences $(\mathrm{p} \leq 0.05)$ in the two seasons, ranging from 1.80 $1.93 \mathrm{dag} \mathrm{kg}^{-1}$ in the rainy season, and $2.15-2.50 \mathrm{dag} \mathrm{kg}^{-1}$ in the dry season (Table 2). On the other hand, the microbial biomass carbon (MBC) was influenced by the gypsum dose in both seasons. In the rainy season, MBC ranged from 625-1294 $\mu \mathrm{g}$ $\mathrm{g}$ soil $^{-1}$, with a higher value found in the treatment with $7 \mathrm{t}$ of gypsum (G7.0), whilst in the dry season, MBC ranged from

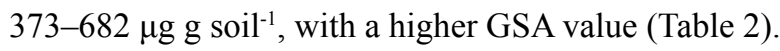

Soil basal respiration (SBR) presented statistical differences in the rainy season, being influenced by the doses of gypsum, with higher values for G7.0, followed by GSA, with lower values for G3.5 and G14 (Table 2). In the dry season, however, SBR did not differ $(\mathrm{p} \leq 0.05)$ between treatments.

Table 2: Total organic carbon (TOC), microbial biomass carbon (MBC), basal respiration (SBR), metabolic coefficient $\left(q \mathrm{CO}_{2}\right)$, microbial coefficient $(q \mathrm{Mic})$ and enzymatic activities of urease, acid phosphatase and hydrolysis of fluorescein diacetate (FDA) of the soil under cultivation of coffee submitted to different doses of agricultural gypsum, in the depth of 0.00-0.10 m. GSA: no agricultural gypsum application; G3.5: $3.5 \mathrm{t} \mathrm{ha}^{-1}$ of agricultural gypsum; G7.0: $7.0 \mathrm{t} \mathrm{ha}^{-1}$ of agricultural gypsum; G14: $14 \mathrm{t} \mathrm{ha-1}$ of agricultural gypsum.

\begin{tabular}{|c|c|c|c|c|c|c|c|c|}
\hline Treatments & TOC & $\mathrm{MBC}$ & SBR & $q \mathrm{CO}_{2}$ & $q \mathrm{Mic}$ & Urease & Phosphatase & FDA \\
\hline $\mathrm{t} \mathrm{ha}^{-1}$ & dag $\mathrm{kg}^{-1}$ & $\mu \mathrm{g} \mathrm{g}^{-1}$ & $\mathrm{mg} \mathrm{g}^{-1} \mathrm{~h}^{-1}$ & $\begin{array}{c}\mathrm{mg} \mathrm{C}-\mathrm{CO}_{2} \mu \mathrm{g}^{-1} \\
\mathrm{CBM}\end{array}$ & $\begin{array}{c}\mu \mathrm{g} \mathrm{CBM} \mathrm{mg} \mathrm{m}^{-1} \\
\text { COT }\end{array}$ & $\mu \mathrm{g} \mathrm{NH}_{4}^{+} \mathrm{g}^{-1} \mathrm{~h}^{-1}$ & $\mu \mathrm{g} \mathrm{PNF}^{-1} \mathrm{~h}^{-1}$ & $m g \mathrm{Fg}^{-1} \mathrm{~h}^{-1}$ \\
\hline & \multicolumn{8}{|c|}{ Rainy season } \\
\hline GSA & $1.80 \pm 0.03 \mathrm{a}$ & $625 \pm 14.0 \mathrm{~b}$ & $5.78 \pm 0.42 \mathrm{~b}$ & $9.29 \pm 0.87 \mathrm{a}$ & $0.38 \pm 0.08 \mathrm{a}$ & $8.78 \pm 0.70 \mathrm{~b}$ & $1269 \pm 85.9 \mathrm{a}$ & $294 \pm 2.61 \mathrm{a}$ \\
\hline G3.5 & $1.93 \pm 0.11 \mathrm{a}$ & $714 \pm 16.2 \mathrm{~b}$ & $4.14 \pm 0.53 \mathrm{c}$ & $5.82 \pm 0.83 \mathrm{~b}$ & $0.28 \pm 0.04 \mathrm{a}$ & $13.5 \pm 0.90 \mathrm{a}$ & $1151 \pm 20.0 \mathrm{a}$ & $305 \pm 3.13 \mathrm{a}$ \\
\hline G7.0 & $1.93 \pm 0.15 \mathrm{a}$ & $1294 \pm 3.47 \mathrm{a}$ & $10.9 \pm 0.33 \mathrm{a}$ & $8.49 \pm 0.24 \mathrm{a}$ & $0.22 \pm 0.03 \mathrm{a}$ & $12.4 \pm 0.76 \mathrm{a}$ & $1058 \pm 43.6 \mathrm{a}$ & $297 \pm 0.49 \mathrm{a}$ \\
\hline \multirow[t]{2}{*}{ G14 } & $1.85 \pm 0.12 \mathrm{a}$ & $457 \pm 50.1 \mathrm{c}$ & $4.50 \pm 0.21 \mathrm{c}$ & $10.02 \pm 0.88 \mathrm{a}$ & $0.20 \pm 0.02 \mathrm{a}$ & $15.8 \pm 0.85 \mathrm{a}$ & $1263 \pm 55.4 \mathrm{a}$ & $297 \pm 5.32 \mathrm{a}$ \\
\hline & \multicolumn{8}{|c|}{ Dry season } \\
\hline GSA & $2.15 \pm 0.10 \mathrm{a}$ & $682 \pm 157 \mathrm{a}$ & $7.05 \pm 1.51 \mathrm{a}$ & $11.97 \pm 4.44 \mathrm{a}$ & $0.50 \pm 0.19 \mathrm{a}$ & $11.9 \pm 1.48 \mathrm{~b}$ & $2551 \pm 149$ a & $321 \pm 2.38 \mathrm{a}$ \\
\hline G3.5 & $2.50 \pm 0.10 \mathrm{a}$ & $476 \pm 9.00 \mathrm{~b}$ & $5.53 \pm 0.64 \mathrm{a}$ & $11.66 \pm 1.54 \mathrm{a}$ & $0.30 \pm 0.03 \mathrm{a}$ & $22.0 \pm 2.50 \mathrm{a}$ & $2595 \pm 346 \mathrm{a}$ & $324 \pm 8.50 \mathrm{a}$ \\
\hline G7.0 & $2.39 \pm 0.20 \mathrm{a}$ & $400 \pm 23.0 \mathrm{~b}$ & $5.60 \pm 0.86 \mathrm{a}$ & $13.84 \pm 2.52 \mathrm{a}$ & $0.65 \pm 0.13 \mathrm{a}$ & $16.8 \pm 5.68 \mathrm{~b}$ & $2402 \pm 370 \mathrm{a}$ & $336 \pm 7.74 \mathrm{a}$ \\
\hline G14 & $2.24 \pm 0.23 \mathrm{a}$ & $373 \pm 35.0 \mathrm{~b}$ & $5.01 \pm 0.73 \mathrm{a}$ & $13.93 \pm 3.11 \mathrm{a}$ & $0.18 \pm 0.06 \mathrm{a}$ & $23.1 \pm 3.44 \mathrm{a}$ & $2275 \pm 130$ a & $334 \pm 10.1 \mathrm{a}$ \\
\hline
\end{tabular}

Treatments followed by the same letter did not differ statistically according to the Scott-Knott test $(p \leq 0.05)$. 
The $q \mathrm{CO}_{2}$ ranged from $5.82-10.02 \mathrm{mg} \mathrm{C}-\mathrm{CO}_{2} \mu \mathrm{g}^{-1}$ $\mathrm{MBC}$ in the rainy season, with lower values in G3.5 (Table 2), while in the dry season, $q \mathrm{CO}_{2}$ did not differ statistically $(\mathrm{p} \leq$ 0.05 ). The $q \mathrm{Mic}$ did not differ between the treatments in both

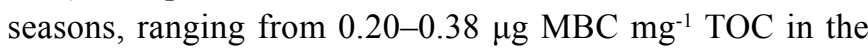
rainy season and from $0.18-0.65 \mu \mathrm{g} \mathrm{MBC} \mathrm{mg}^{-1} \mathrm{TOC}$ in the dry season.

In general, the enzymatic activities of the soil were not able to stratify the treatments, except for Urease, in both seasons (Table 2). Urease activity ranged from 8.78-15.8 $\mu \mathrm{g} \mathrm{NH}_{4}^{+} \mathrm{g}^{-1} \mathrm{~h}^{-1}$ in the rainy season, with higher values for G14, G3.5, and G7.0, with the lowest values for GSA, while in the dry season it ranged from 11.9-23.1 $\mu \mathrm{g} \mathrm{NH}_{4}^{+} \mathrm{g}^{-1} \mathrm{~h}^{-1}$, with higher values for G14 and G3.5, and lower for GSA and G7.0. However, despite the gypsum rates differing among themselves, it was not possible to check a trend and define the best treatment for this parameters. As for the FDA and phosphatase, they were not significantly affected by the treatments, with great variability in the data, but without the tendency of relating to the dose of gypsum applied.

The specific enzymatic activities by microbial biomass carbon were key when indicating the divergence between the treatments, presenting statistical differences for all the enzymes ( $\mathrm{p} \leq 0.05$ ) (Figure 1). Specific activity of Urease by MBC presented higher values in G14 treatment in the rainy season, and in the G3.5, G7.0 and G14 treatments in the dry season (Figure 1). During the rainy season, the specific activity of Phosphatase $\mathrm{MBC}^{-1}$ was higher in $\mathrm{G} 14$, followed in descending order by GSA, G3.5, and G7.0, as in the dry season, however, there were no statistical differences between treatments $(\mathrm{p} \leq$ 0.05). The FDA $\mathrm{MBC}^{-1}$ did not present statistical differences between treatments $(\mathrm{p} \leq 0.05)$ in the rainy season, but in the dry season, it was observed that G14 and G7.0 presented greater activities, followed by G3.5 and GSA. Following the trend set by the absolute enzymes, the specific enzymatic activities were higher in the dry season (Figure 1).

Productivity during the four years (2011-2014) of cultivation was added together and resulted in the accumulated productivity that is shown in Figure 2. The accumulated productivity demonstrated that G14 was the best treatment, followed by G3.5, with lower productivities being parameters to GSA and G7.0 (Figure 2). The application of $3.5 \mathrm{t} \mathrm{ha}^{-1}$ of agricultural gypsum led to productivity increases of $10 \%$, while the application of $14 \mathrm{tha}^{-1}$ increased productivity by $25 \%$.

The principal component analysis was important to validate, through different parameters, a separation of the treatments with doses of gypsum in the coffee crops, in both seasons (Figure 3). In the rainy season, it is observed that component 1 ( $\mathrm{PC} 1$ ) explained $43.43 \%$ of the variability, while PC2 explained $21.92 \%$, accumulating $65.34 \%$. The variables Urease, Phosphatase and Accumulated Productivity correlated positively with PC1, MBC and SBR correlated negatively with PC1, and TOC correlated with PC2 (Table 3). In the dry season, we observed that PC1 explained $38.70 \%$ of variability and PC2 $20.34 \%$, representing a total of $59.05 \%$ in data variability. The variables Urease and Accumulated Productivity were positively correlated and $\mathrm{MBC}$ and Phosphatase negatively correlated with PC1, whilst the FDA correlated negatively with PC2.

In the rainy season, there was a clear divergence between treatments (Figure 3). The G7.0 treatment was different due to its high correlations with MBC and SBR, and G3.5 was different in relation to TOC levels, and Urease and FDA activities. Moreover, G14 was separated by Accumulated Productivity and by the activity of Phosphatase. The GSA showed the dispersion between the other treatments, without the influence of specific variables in these PCs (Figure 3). In the dry season, there was not a clear divergence between the treatments, and greater dispersion of the points in G14 and G3.5 was observed. In general, G14, G3.5, and G7.0 were influenced by the activities of the FDA, Urease, and Phosphatase, Accumulated Productivity and TOC, and GSA by their MBC and SBR (Figure 3).

\section{DISCUSSION}

The results of this study show that the application of high doses of agricultural gypsum in the coffee lines modifies the biomass and the microbial activities in the soil. The dose of $7 \mathrm{t} \mathrm{h}^{-1}$ promotes the greatest MBC and SBR. The dose of $14 \mathrm{t} \mathrm{ha}^{-1}$ favored the largest specific enzymatic activities by microbial biomass and the accumulated coffee yield over the four years of cultivation. In our research, we evaluated the residual effect of the application of agricultural gypsum over five years after its application. Having seen that there were several harvests and seasonal cycles of winter and summer, we can observe that the microbiological and productivity activities were higher in the highest applied doses of gypsum, which indicates the more prolonged residual effect of these doses. Probably, where lower doses were applied, it would be necessary to apply new doses in an interval of less than five years, in order to obtain results similar to those in which agricultural gypsum super dosages were applied. However, it is necessary that more specific assessments are made in order to prove this hypothesis.

Coffee cultivation in the Upper São Francisco region (MG-Brazil) is exposed to the weather, in some cases requiring irrigation or the implementation of special techniques that increase the retention and the water storage in the soil (Martins et al., 2007). The practice of gypsum in the coffee culture in this region was adopted in order to allow the plants to increment their root system and explore a greater volume of soil and to increase the absorption of water and nutrients, thereby maintaining greater vegetative vigor during most of the year, even in times of drought (Carducci et al., 2014a; Ramos et al., 2013; Serafim et al., 2013; Silva et al., 2015; Silva et al., 2019a). 


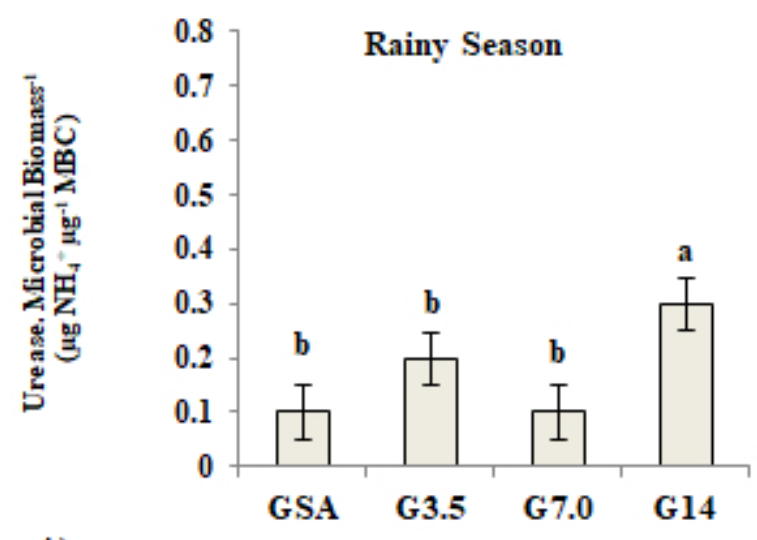

A)
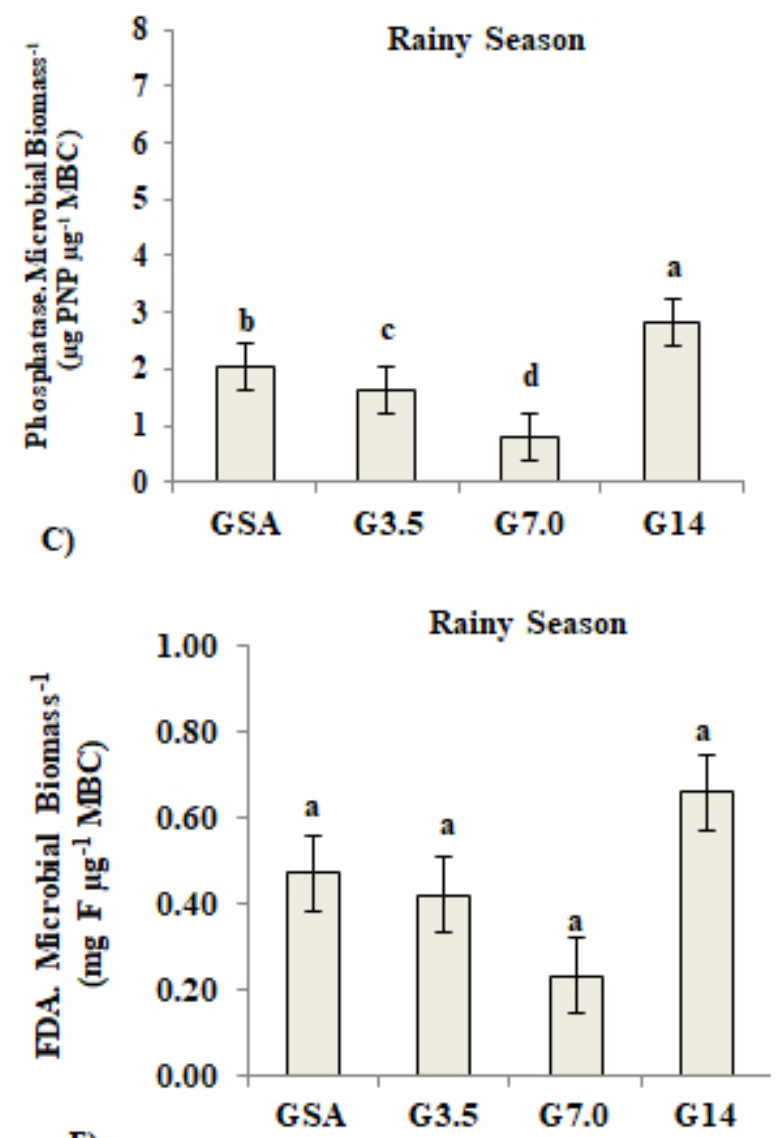

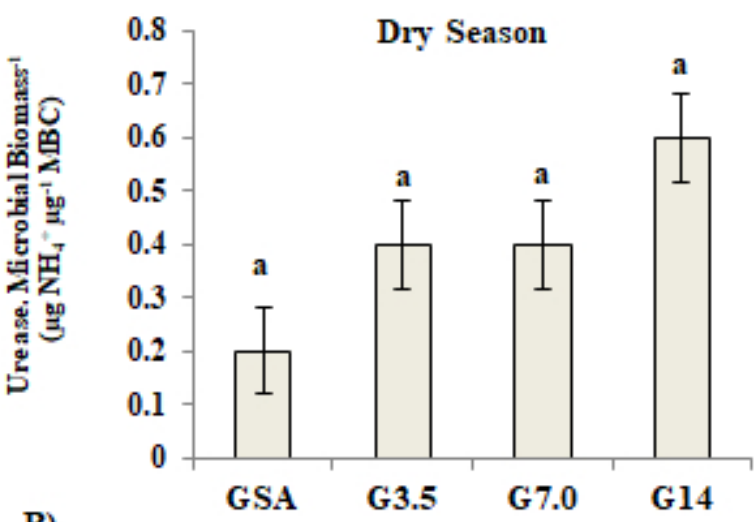

B)
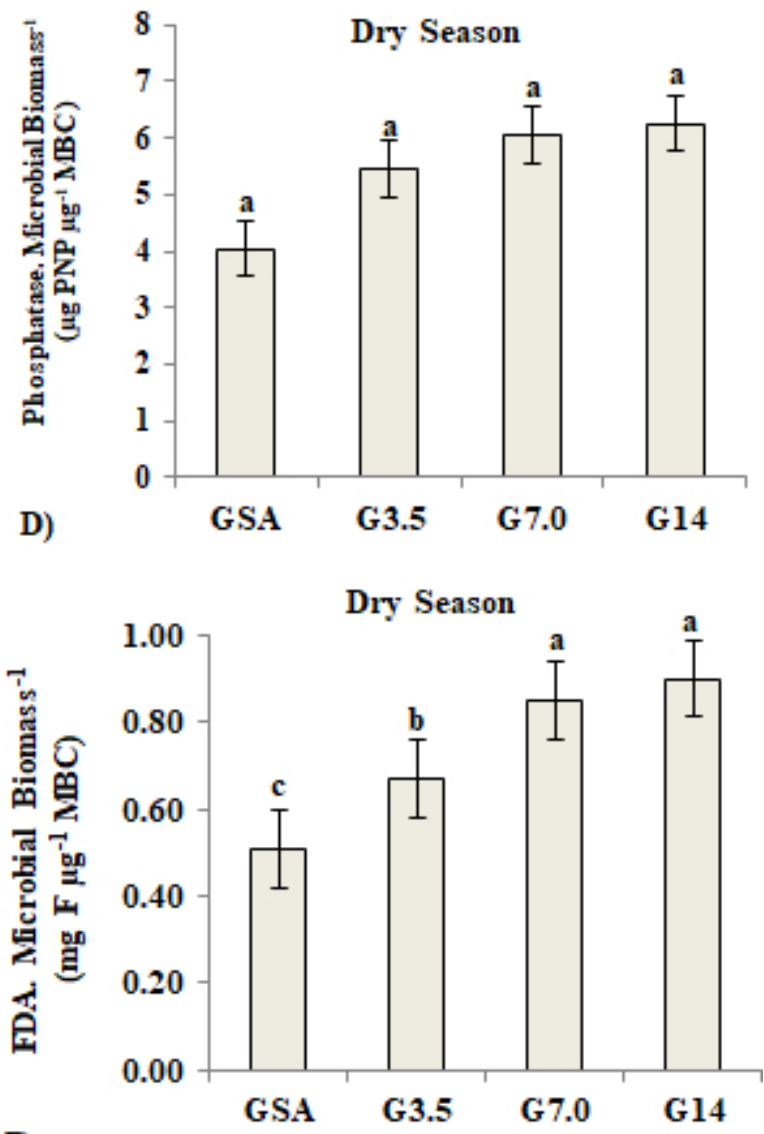

Figure 1: Specific enzymatic activity per unit of soil microbial biomass carbon under coffee cultivation submitted to different doses of agricultural gypsum, in the depth of $0.00-0.10 \mathrm{~m}$. Urease. Microbial Biomass ${ }^{-1}$ (A and B); Phosphatase. Microbial Biomass ${ }^{-1}$ ( $C$ and D); Fluorescein Diacetate Hydrolysis. Microbial Biomass-1 (E and F). GSA: no agricultural gypsum application; G3.5: 3.5 $\mathrm{t} \mathrm{ha}^{-1}$ of agricultural gypsum; G7.0: $7.0 \mathrm{t} \mathrm{ha}^{-1}$ of agricultural gypsum; G14: $14 \mathrm{t} \mathrm{ha}^{-1}$ of agricultural gypsum. Standard error bar.

Despite the benefits that the application of gypsum has on crop yields, the use of super dosages of agricultural gypsum has been employed without technical criteria and little is known of the effects on the physical, chemical and biological parameters of the soil. Silva et al. (2019b) observed that the application of high doses of gypsum reduced the water stress of coffee plants, in the same area of research, which could be a potential problem in the cultivation affecting productivity. However, the same authors observed that the greatest productivities were e obtained via treatment without gypsum in 2011 and in the treatment with $28 \mathrm{t} \mathrm{ha}^{-1}$ of gypsum in 2012, which demonstrates both the biannual effects of the crops and other edaphoclimatic factors, which are independent of the treatments that were applied, influencing coffee productivity. It is worth mentioning that 3.5 $\mathrm{t} \mathrm{ha}^{-1}$ is the soil gypsum dose recommended by soil analysis (Sousa; Lobato; Rein, 2004). On the other hand, the microbiota 
of the soil was sensitive, demonstrating the interference of the doses of gypsum in the edaphic parameters, which were also influenced by the climatic season, with higher values in the treatments that received 7 and $14 \mathrm{t} \mathrm{ha}^{-1}$.

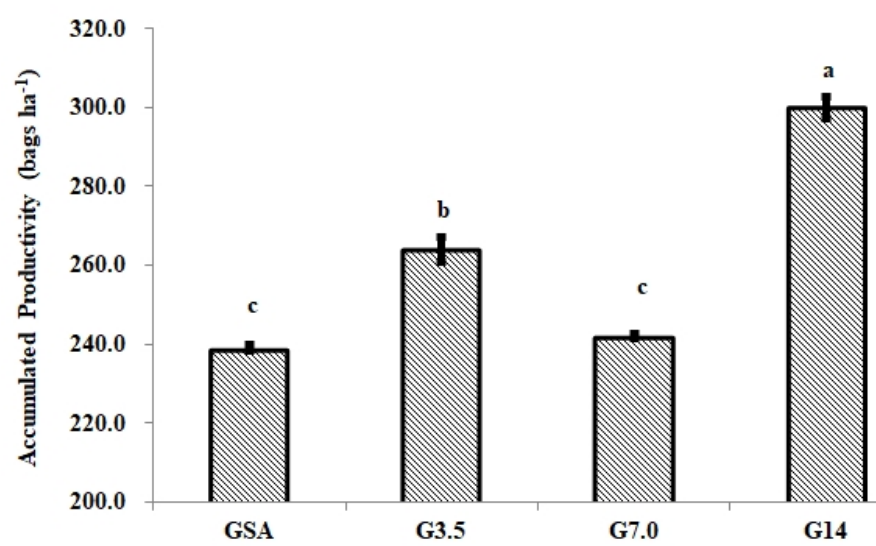

Figure 2: Accumulated productivity of the 2011, 2012, 2013 and 2014 harvests in bags ha-1 of coffee submitted to different doses of agricultural gypsum, in the depth of $0.00-0.10 \mathrm{~m}$. GSA: no agricultural gypsum application; G3.5: $3.5 \mathrm{t} \mathrm{ha}^{-1}$ of agricultural gypsum; G7.0: $7.0 \mathrm{t} \mathrm{ha}^{-1}$ of agricultural gypsum; G14: $14 \mathrm{t} \mathrm{ha}^{-1}$ of agricultural gypsum. Standard error bar.

The highest biomass and microbial respiration were observed in the dose of $7 \mathrm{t} \mathrm{ha}^{-1}$ in the rainy season. The average MBC was $777 \mu \mathrm{g} \mathrm{g} \mathrm{soil}{ }^{-1}$ in the rainy season and $482 \mu \mathrm{g} \mathrm{g}$ soil $^{-1}$ in the dry season (Table 2), which indicates an adequate value for Cerrado Latosols, according to Lopes et al. (2013). The relative differences in soil biological parameters values at both seasons are strongly influenced by seasonal changes. The soils of the Cerrado are exposed to a characteristic climatic condition, with two well defined seasons, being dry winter and rainy summer. These seasonal changes alter the moisture content and the availability of water in the soil, which influences the metabolic activities and even the diversity of soil microorganisms (Carneiro et al., 2008; Castro et al., 2016; Silva et al., 2018).

With gypsum, there is an increase in the availability of water and nutrients throughout the soil profile, especially $\mathrm{Ca}^{+2}$, which favors a greater presence of fine roots in the coffee tree (Carducci et al., 2014a; Carducci et al., 2015; Ramos et al., 2013). This increase in the number of roots may have influenced the increase of $\mathrm{MBC}$ and microbial activities in treatments with high doses of gypsum due to the entry of carbon via the rhizodeposition of organic compounds. However, due to the high sensitivity of these parameters, they are subject to changes, such as climatic ones.

The fact that the enzymes FDA and Phosphatase (Table 2) have not been significantly affected by the treatments is due to a large number of biotic and abiotic factors that interfere with the activity of the enzymes in the soil. Unlike the FDA and Phosphatase, Urease was heavily influenced by treatments, but the effect of the doses of gypsum was not the same among the seasons, so it was not possible to indicate the best dose to promote greater activity of this enzyme. The enzymes can be immobilized in the mineral fractions of the soil, and their activity is conditioned by factors such as the type of vegetation, management practices, $\mathrm{pH}$, moisture content, temperature, aggregate stability and soil organic matter content (Raiesi; Beheshti, 2014; 2015; Silva et al., 2019b).
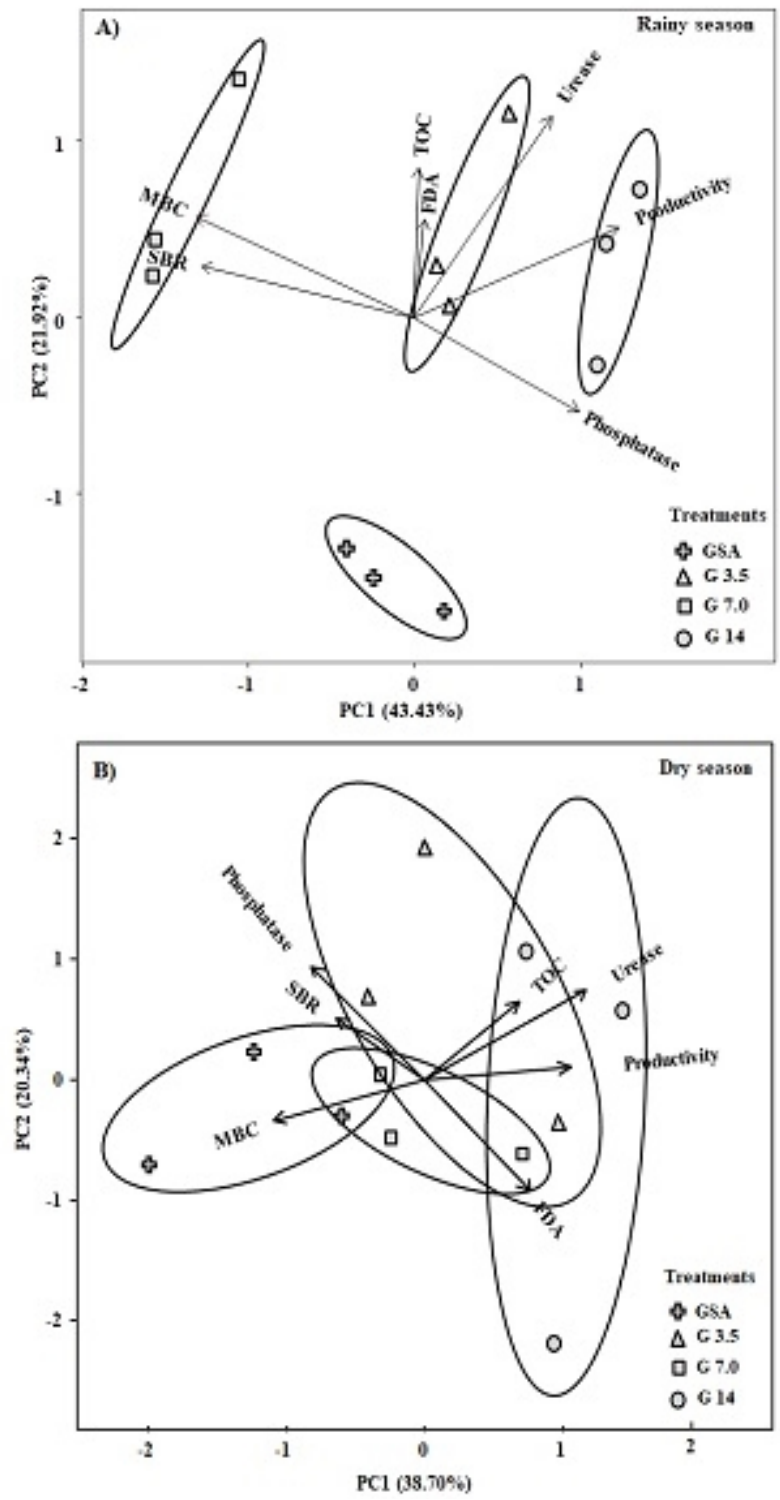

Figure 3: Principal component analysis (PCA) of soil biochemical parameters under coffee cultivation submitted to different doses of agricultural gypsum, in the depth of $0.00-0.10 \mathrm{~m}$. GSA: no agricultural gypsum application; G3.5: $3.5 \mathrm{t} \mathrm{ha}^{-1}$ of agricultural gypsum; G7.0: $7.0 \mathrm{t} \mathrm{ha}^{-1}$ of agricultural gypsum; G14: $14 \mathrm{t} \mathrm{ha-1}$ of agricultural gypsum. Total organic carbon (TOC), microbial biomass carbon (MBC), basal respiration (SBR), and hydrolysis of fluorescein diacetate (FDA). 
Table 3: Eigenvalues of biochemical parameters of the soil under coffee cultivation submitted to different doses of agricultural gypsum, in the depth of $0.00-0.10 \mathrm{~m}$. GSA: no agricultural gypsum application; G3.5: $3.5 \mathrm{t} \mathrm{ha}^{-1}$ of agricultural gypsum; $\mathrm{G} 7.0$ : $7.0 \mathrm{t} \mathrm{ha}^{-1}$ of agricultural gypsum; G14: $14 \mathrm{t} \mathrm{ha}^{-1}$ of agricultural gypsum.

\begin{tabular}{ccccc}
\hline $\begin{array}{c}\text { Importance of } \\
\text { components }\end{array}$ & \multicolumn{2}{c}{ Rainy season } & \multicolumn{2}{c}{ Dry season } \\
\hline Eigenvalue & 3.0399 & 1.5341 & 2.709 & 1.424 \\
Proportion Explained & $43.43 \%$ & $21.92 \%$ & $38.70 \%$ & $20.34 \%$ \\
Cumulative Proportion & $43.43 \%$ & $65.34 \%$ & $38.70 \%$ & $59.05 \%$ \\
& & Species scores & \\
TOC & 0.06 & 0.65 & 0.52 & 0.50 \\
MBC & -1.00 & 0.44 & -0.84 & -0.26 \\
SBR & -0.98 & 0.22 & -0.49 & 0.39 \\
Urease & 0.63 & 0.87 & 0.90 & 0.56 \\
Phosphatase & 0.75 & -0.41 & -0.62 & 0.72 \\
FDA & 0.04 & 0.42 & 0.58 & -0.70 \\
Accumulated Productivity & 0.94 & 0.39 & 0.81 & 0.08 \\
\hline
\end{tabular}

Total organic carbon (TOC), microbial biomass carbon (MBC), basal respiration (SBR), hydrolysis of fluorescein diacetate (FDA).

The high activity of the enzymes studied corroborates with Lopes et al. (2013) and was probably influenced by the integrated management in the coffee plantation, which maintains the interweaving covered in grass. The presence of a greater diversity of plants in the cultivation system stimulates the decomposing microbiota in the rhizosphere of the plants and leads to increases in the enzymatic activities in the soil, mainly due to the stimulation of microbial growth by the release of different exudates in the rhizosphere (Verbruggen et al., 2016). The application of the agricultural gypsum also stimulates greater rhizodeposition by the deepening of the root system (Carducci et al., 2014a; Ramos et al., 2013).

In order to observe the effects of soil microbial biomass on the enzymatic activity of the soil, several studies have used specific enzymes, that is, the relationship between the activity of the enzyme and the soil microbial biomass, thus comparing the biochemical activity with the soil microbial $\mathrm{C}$ content (Raiesi; Beheshti, 2014; Trasar-Cepeda; Leirós; GilSotres, 2008). This variable has been shown to be an efficient bioindicator of soil quality in relation to changes in soil use (Raiesi; Beheshti, 2015; Silva et al., 2018; Silva et al., 2019b). The specific enzymatic activities were sensitive to the different doses of gypsum applied to the soil under coffee cultivation, in general, with an increase in specific activity in relation to the dose increase, with clearer differences in the rainy season, with emphasis on the dose of $14 \mathrm{t} \mathrm{ha}^{-1}$, which is also the dose with the highest productivity of coffee plants.
By relating soil biological indicators to the cumulative relative yield of different cropping systems in the Cerrado de Planaltina-DF-Brazil, Lopes et al. (2013) obtained results that demonstrate the efficiency of biological activities and microbial biomass in indicating whetherthe cultivation system is efficient, because from the bioindicators of the soil a productive response can be estimated, that is, where there are higher values of activities and microbial biomass, there will be possibilities of higher productivity. The productivity of the coffee tree followed a trend of increasing with the dose of agricultural gypsum, as well as the specific enzymatic activities, with higher values in the treatment G14, which was the treatment with the highest dose of gypsum (Figure 2).

The accumulated productivity showed that the application of $14 \mathrm{t}$ of gypsum per ha resulted in the production of 300 bags ha $^{-1}$ of coffee, with increases of $25 \%$ in relation to the control without application of gypsum (Figure 2), showing significant gain in the harvests evaluated. It was observed that coffee, even at the beginning of production, showed gains from this agricultural management. The application of gypsum enables coffee plants to develop a deep root system (Carducci et al., 2014b), which increases the access to water in depth, important to overcome the effects of seasonality in productivity (Silva et al., 2019a), and to have a higher absorption of nutrients that are in the subsurface, mainly $\mathrm{Ca}^{+2}, \mathrm{Mg}^{+2}$ and $\mathrm{K}^{+}$(Ramos et al., 2013), which results in increases in crop productivity allowing for increases in soil microbial activity.

Principal component analysis (Figure 3) separated and grouped gypsum dose treatments, demonstrating that soil biochemical parameters were key in differentiating the treatments. In the rainy season, the G7.0 treatment was separated by its higher SBR and MBC. The enzymatic activities of Urease and the FDA were strongly influenced by TOC and these variables were grouped together influencing the G3.5 treatments. G14 treatment was influenced by higher productivity and Acid Phosphatase activity (Figure 3). It is also observed that during the dry season, the replications of all the treatments were more dispersed than in the rainy season (Figure 3), showing multiple influences caused by the variables in this dispersion of the replications, showing that these two PCs were not enough to characterize the influences of each variable in each treatment.

\section{CONCLUSIONS}

The results presented in this study confirm that the biochemical parameters of the soil are key in the evaluation of changes in soil use, and that the increase in agricultural gypsum, in 7 and $14 \mathrm{t} \mathrm{ha}^{-1}$ favored the activity, microbial biomass and productivity, wherein this practice is important to maintain the plant's water supply and overcome the problems arising from the climatic seasonality in the Cerrado region, regarding the limits presented above. 


\section{ACKNOWLEDGMENTS}

We thank the Coordenação de Aperfeiçoamento de Pessoal de Nível Superior (Capes), the Conselho Nacional de Desenvolvimento Científico e Tecnologia (CNPq), and the Fundação de Amparo à Pesquisa de Minas Gerais (Fapemig) for the financial support and scholarships granted to the authors.

\section{REFERENCES}

ALEF, K. Estimation of soil respiration. In: ALEF, K.; NANNIPIERI, P. (Eds.). Methods in applied soil microbiology and biochemistry. Academic Press, New York, p.464-470, 1995.

ANDERSON, T. H.; DOMSCH, K. H. The metabolic quotient for $\mathrm{CO}_{2}\left(q \mathrm{CO}_{2}\right)$ as a specific activity parameter to assess the effects of environmental conditions, such as $\mathrm{pH}$, on the microbial biomass of forest soils. Soil $\boldsymbol{\&}$ Tillage Research, 25:393-395, 1993.

CARDUCCI, C. E. et al. Distribuição espacial das raízes de cafeeiro e dos poros de dois Latossolos sob manejo conservacionista. Revista Brasileira de Engenharia Agrícola e Ambiental, 18:270-278, 2014a.

CARDUCCI, C. E. et al. Gypsum effects on the spatial distribution of coffee roots and the pores system in oxidic Brazilian Latosol. Soil \& Tillage Research, 145:171-180, 2015.

CARDUCCI, C. E. et al. Spatial variability of pores in oxidic latosol under a conservation management system with different gypsium doses. Ciência e Agrotecnologia, $38: 445-460,2014 b$.

CARNEIRO, M. A. C. et al. Atributos físicos, químicos e biológicos de solo de cerrado sob diferentes sistemas de uso e manejo. Revista Brasileira de Ciência do Solo, 33:147-157, 2009.

CARNEIRO, M. A. C. et al. Carbono orgânico, nitrogênio total, biomassa e atividade microbiana do solo em duas cronossequências de reabilitação após a mineração de bauxita. Revista Brasileira de Ciência do Solo, 32:621632,2008

CASTRO, A. P. et al. Microbial diversity in cerrado biome (Neotropical Savanna) Soils. PLoS One, 11(2):e0148785, 2016.

COUTO, C. C. et al. Coffea arábica and C. canephora discrimination in roasted and ground coffee from reference material candidates by real-time PCR. Food Research International, 115:227-233, 2019.
DICK, R. P.; BREAKWELL, D. P.; TURCO, R. F. Soil enzyme activities and biodiversity measurements as integrative microbiological indicators. In: DORAN, J. W.; JONES, A. J. (Eds.). Methods for Assessing Soil Quality. Soil Science Society of America, Madison, p.247-272, 1996.

DORAN, J. W.; ZEISS, M. R. Soil health and sustainability: Managing the biotic component of soil quality. Applied Soil Ecology, 15:3-11, 2000.

EIVAZI, F.; TABATABAI, M. A. Phosphatases in soils. Soil Biology \& Biochemistry, 9:167-172, 1977.

FERREIRA, D. F. Sisvar: A computer statistical analysis system. Ciência e Agrotecnologia, 35:1039-1042, 2011.

KEENEY, D. R.; NELSON, D. W. Nitrogen organic forms. In: PAGE, A. L. (Ed). Methods of soil analysis: Chemical and microbiological properties. 2nd ed. Soil Science Society of America, Madison, p.643-698, 1982.

LOPES, A. A. C. et al. Interpretation of microbial soil indicators as a function of crop yield and organic carbon. Soil Science Society of America Journal, 77:461-472, 2013.

LOPES, A. S.; GUILHERME, L. R. G. A career perspective on soil management in the Cerrado region of Brazil. Advances in Agronomy, 137:1-72, 2016.

MARTINS, C. C. et al. Manejo da irrigação por gotejamento no cafeeiro (Coffea arabica L.). Bioscience Journal, 23:61-69, 2007.

MENDES, I. C. et al. Biological functioning of Brazilian Cerrado soils under different vegetation types. Plant Soil, 359:183-195, 2012.

MYERS, N. et al. Biodiversity hotspots for conservation priorities. Nature, 403:853-858, 2000.

R DEVELOPMENT CORE TEAM. R: A language and environment for statistical computing. Vienna, Austria: R Foundation for Statistical Computing Retrieved. 2011. Available in: <from http://www.r-project.org $>$. Access in: January, 05, 2020.

RAIESI, F.; BEHESHTI, A. Microbiological indicators of soil quality and degradation following conversion of native forests to continuous croplands. Ecological Indicators, 50:173-185, 2015.

RAIESI, F.; BEHESHTI, A. Soil specific enzyme activity shows more clearly soil responses to paddy rice cultivation than absolute enzyme activity in primary forests of northwest Iran. Applied Soil Ecology, 75:63-70, 2014. 
RAMOS, B. Z. et al. Doses de gesso em cafeeiro: Influência nos teores de cálcio, magnésio, potássio e pH na solução de um Latossolo Vermelho distrófico. Revista Brasileira de Ciência do Solo, 37:1018-1026, 2013.

SANTOS, T. B. et al. An integrated analysis of mRNA and sRNA transcriptional profiles in Coffea arabica L. roots: Insights on nitrogen starvation responses. Functional \& Integrative Genomics, 19:151-169, 2019.

SERAFIM, M. E. et al. Potencialidades e limitações de uso de Latossolos e Cambissolos, sob sistema conservacionista em lavouras cafeeiras. Bioscience Journal, 29:1640-1652, 2013.

SILVA, A. O. et al. Soil microbiological attributes indicate recovery of an iron mining area and of the biological quality of adjacent phytophysiognomies. Ecological Indicators, 93:142-151, 2018.

SILVA, B. M. et al. Critical soil moisture range for a coffee crop in an oxidic latosol as affected by soil management. Soil \& Tillage Research, 154:103-113, 2015.

SILVA, B. M. et al. Soil moisture associated with least limiting water range, leaf water potential, initial growth and yield of coffee as affected by soil management system. Soil \& Tillage Research, 189:36-43, 2019a.

SILVA, E. A. et al. Aggregate stability by the "high energy moisture characteristic" method in an oxisol under differentiated management. Revista Brasileira de Ciência do Solo, 38:1633-1642, 2014.

SILVA, E. A. et al. Doses crescentes de gesso agrícola, estabilidade de agregados e carbono orgânico em Latossolo do Cerrado sob Cafeicultura. Revista de Ciências Agrárias: Amazonian Journal of Agricultural and Environmental Sciences, 56:25-32, 2013.

SILVA, É. O. et al. Seasonal effect of land use type on soil absolute and specific enzyme activities in a Brazilian semi-arid region. Catena, 172:397-407, 2019b.
SOUSA, D. M. G.; LOBATO, E.; REIN, T. A. Uso do gesso agrícola nos solos do Cerrado. 2. ed. Planaltina: EMBRAPA-CPAC. 2005. Available in: http:// bbeletronica.cpac.embrapa.br/2005/cirtec/cirtec_32.pdf. Access in: January, 05, 2020.

SPARLING, G. P. Ratio of microbial biomass carbon to soil organic carbon as a sensitive indicator of changes in soil organic matter. Australian Journal of Soil Research, 30:195-207, 1992.

SUMNER, M. E. Amelioration of subsoil acidity with minimum disturbance. In: JAYAWARDANE, N. S.; STEWART, B. A. (Ed.). Subsoil management techniques. Athens: Lewis Publishers, p.147-185, 1995.

TABATABAI, M. A.; BREMNER, J. M. Assay of urease activity in soil. Soil Biology \& Biochemistry, 4:479-487, 1972.

TRASAR-CEPEDA, C.; LEIRÓS, M.; GIL-SOTRES, F. Hydrolytic enzyme activities in agricultural and forest soils. Some implications for their use as indicators of soil quality. Soil Biology \& Biochemistry, 40:2146-2155, 2008.

VANCE, E. D.; BROOKS, P. C.; JENKINSON, D. S. An extraction method for measuring soil microbial biomass C. Soil Biology \& Biochemistry, 19:703-707, 1987.

VERBRUGGEN, E. et al. Do arbuscular mycorrhizal fungi stabilize litter-derived carbon in soil? Journal of Ecology, 104:261-269, 2016.

WALDROP, M. P.; BALSER, T. C.; FIRESTONE, M. K. Linking microbial community composition to function in a tropical soil. Soil Biology \& Biochemistry, 32:18371846, 2000.

WALKLEY, A.; BLACK, I. A. An examination of the Degtjareff method for determining soil organic matter, and proposed modification of the chromic acid titration method. Soil Science, 37:29-38, 1934. 